Piotr KAMIŃSKI ${ }^{1}$, Konrad KRYGIER², Iga DROBINA ${ }^{3}$, Robert DROBINA ${ }^{4}$

Opiekun naukowy: Robert DROBINA ${ }^{4}$

DOI: https://doi.org/10.53052/9788366249837.11

\title{
Projekt SEPARATORA POWIETRZNEgo
}

Streszczenie: W artykule omówiono aspekty prawne związane z składowaniem odpadów komunalnych. Jednym $\mathrm{z}$ istotnych elementów segregacji odpadów są frakcje styropianowe. $\mathrm{Z}$ tego powodu opracowano konstrukcję separatora powietrznego do segregacji styropianu z wymieszanych frakcji metalu, plastiku oraz styropianu. Dla oceny skuteczności skonstruowanej maszyny przeprowadzono próby w rzeczywistych warunkach eksploatacyjnych.

Słowa klucze: Segregacja, separator powietrzny, odpady, projektowanie

\section{AIR SEPARATOR DESIGN}

\begin{abstract}
The article discusses the legal aspects related to the storage of municipal waste. One of the important elements of waste segregation are polystyrene fractions. For this reason, an air separator was developed to segregate polystyrene from mixed fractions of metal, plastic and polystyrene. In order to assess the effectiveness of the constructed machine, tests were carried out in real operating conditions.
\end{abstract}

Keywords: Segregation, sifter, waste, design

\section{Cel i zakres pracy}

Celem niniejszej pracy było przedstawienie aspektów prawnych w zakresie budowy składowisk odpadów komunalnych, a także zaprezentowano projekt i wykonanie separatora powietrznego do segregacji odpadów styropianowych na bazie wentylatora komputerowego. Przeprowadzono próbę pilotażową

\footnotetext{
${ }^{1}$ mgr inż. Akademia Techniczno-Humanistyczna w Bielsku-Białej, Wydział Budowy Maszyn i Informatyki, specjalność: Inżynieria Produkcji email: piotr-pio-kam@wp.pl

${ }^{2}$ Uczeń Zespołu Szkół Elektronicznych, Elektrycznych i Mechanicznych w Bielsku-Białej ${ }^{3}$ Uniwersytet Śląski w Katowicach, Wydział Prawa i Administracji, email: iga.drobina@gmail.com

${ }^{4}$ prof. ATH dr hab. inż., Akademia Techniczno-Humanistyczna w Bielsku-Białej, Wydział Budowy Maszyn i Informatyki, email: rdrobina@ath.bielsko.pl
} 
w warunkach rzeczywistych podczas wypełnienie zsypu zmieszanymi frakcjami styropianowymi, metalowymi i plastikowymi.

Zakres tej pracy obejmował projekt i wykonanie dmuchawy, oraz opis przebiegu projektowania.

\section{Wstęp}

Podstawy prawne w zakresie dopuszczenia budowy składowisk odpadów jako budowli inżynierskich nadają dwa rozporządzenia [1-9]:

Rozporządzenie Rady Ministrów z dnia 9 listopada 2004 roku w sprawie warunków dla przedsięwzięć mogących znacząco oddziaływać na środowisko ( Dz. U. z 2004r. Nr 257, poz. 2573) a także Rady Ministrów z dnia 10 maja 2005 r. zmieniające rozporządzenie w sprawie określenia rodzajów przedsięwzięć mogących znacząco oddziaływać na środowisko oraz szczegółowych uwarunkowań związanych z kwalifikowaniem przedsięwzięcia do sporządzenia raportu o oddziaływaniu na środowisko (Dz. U. z 2005r. nr 92, poz. 769).

W inżynierii lądowej w zakresie zagospodarowania odpadów należy podejmować działania:

- w zakresie regularnego usuwania odpadów z gospodarstw domowych, miast i gmin,

- odpowiedniego postępowania $\mathrm{z}$ nagromadzonymi odpadami, które nie będzie niekorzystnie oddziaływało na środowisko i mieszkańców [10].

Podstawową metodą usuwania, unieszkodliwiania i zagospodarowania odpadów jest w dalszym ciągu ich gromadzenie na składowiskach. Można sklasyfikować składowiska na trzy rodzaje [11]:

- niezorganizowane tj. dzikie,

- półzorganizowane, nieuporządkowane: zorganizowane za zezwoleniem władz,

ale ich eksploatacja nie odpowiada w pełni wymogom ochrony środowiska (np. niewłaściwa lokalizacja ze względu na ochronę wód podziemnych itp.),

- zorganizowane, uporządkowane jako obiekty inżynierskie, niezagrażające zdrowiu publicznemu, minimalizujące zagrożenie dla środowiska, zarówno w trakcie eksploatacji jak i po jej zakończeniu, spełniający kryteria lokalizacyjne i właściwej eksploatacji.

Składowiska odpadów stanowią jedną $\mathrm{z}$ najpopularniejszych metod redukcji odpadów. Przy projektowaniu, budowie i eksploatacji składowiska, należy dążyć do minimalizacji uciążliwości związanych z eksploatacja tych obiektów [12].

W praktyce inżynierskiej składowiska należą do najtrudniejszych budowli ze względu na następujące cechy [12]:

- powierzchnia od kilku do kilkuset tysięcy metrów kwadratowych,

- $\quad$ pojemność od kilku tysięcy do kilkunastu milionów metrów sześciennych odpadów,

- okres eksploatacji do kilkudziesięciu lat,

- maksymalna szczelność i minimalne oddziaływanie na otoczenie.

Zależnie od wybranej lokalizacji i topografii terenu wyróżnić można następujące formy położenia i kształtu składowisk [13]: 
- położenie wgłębne, a więc składowiska zlokalizowane w wyrobiskach poeksploatacyjnych, wąwozach, nieckach polodowcowych oraz innych obniżeniach terenu). Zaletą tej lokalizacji jest osłonowe działanie skarp, wadą natomiast nadmierne gromadzenie wód opadowych zwłaszcza przy położeniu bezodpływowym,

- położenie zboczowe (skarpowe) stanowiące fragmenty parowów, kotlin górskich, niecek i rynien polodowcowych, wyrobisk pokopalnianych, zwałowisk odpadów mineralnych, nasypów ziemnych,

- położenie na terenie płaskim.

W zależności od ukształtowania terenu stosuje się różne formy deponowania odpadów:

- $\quad$ podłużne i kombinowane na terenach o bogatej rzeźbie w zależności od wielkości spadku terenu,

- na terenach płaskich odpady gromadzi się albo przez usypywanie kopców i pryzm albo przez układanie odpadów we wcześniej przygotowanych rowach o głębokości 3 do $8 \mathrm{~m}$.

Zgodnie z wymaganiami zawartymi w Dyrektywach Unijnych składowiska powinny posiadać odpowiednią i specjalną lokalizacje, Winny również spełniać warunki przeciwdziałania uwalniania się odorów, niekontrolowanej emisji gazu wysypiskowego, jak również zapewniać ochronę przed hałasem [13].

Składowiska jako obiekty muszą być projektowane i wykonywane z uwzględnieniem drenażu wód powierzchniowych, drenażu odprowadzania gazu wysypiskowego, przy minimalizacji infiltracji wód opadowych do złoża odpadów (uszczelnienie warstwy wierzchniej), przy stosowaniu drenażu odcieków ze składowiska oraz odpowiednim uszczelnieniu dna i boków składowiska dla przeciwdziałania migracji odcieków poza obszar składowiska. Ponadto projekt każdego składowiska powinien określać następujące elementy [13]:

- powierzchnię, objętość i granice składowiska: wyznaczać obszar obecny, docelowy oraz strefę ochronną,

- drogi dojazdowe o trwałej nawierzchni oraz tymczasowe drogi do stref wyładunku odpadów,

- $\quad$ sposób eksploatacji na sucho lub jako reaktor biologiczny, a także metodę eksploatacji powierzchniową lub kwaterową w wykopie,

- wielkość odcieków oraz określenie sposobu ich unieszkodliwiania przed ich odprowadzeniem do oczyszczalni ścieków,

- $\quad$ produkcję gazu: odgazowanie aktywne oraz pasywne celem zapobieżenia migracji poza teren składowiska,

- sposób zagospodarowania odpadów komunalnych po zamknięciu składowiska,

- monitoring wód gruntowych, wód powierzchniowych oraz rozprzestrzeniana

się gazu poza składowisko,

- $\quad$ inne elementy jak np. zagrożenie pożarowe.

W Polsce obowiązkowo segregujemy odpady na 5 frakcji: szkło, odpady zmieszane, papier, plastiki i metal bioodpady [14].Odzyskane szkło przerabia się na stłuczkę szklaną jest to materiał pozyskiwany ze zbędnych i zniszczonych wyrobów szklanych [14]. Ten surowiec może być wykorzystywany niezliczoną ilość 
razy gdyż nie traci przy tym, na jakości [15]. Przy recyklingu szkła istotne jest oddzielenie szkła płaskiego od opakowaniowego gdyż maja różną temperaturę topnienia i inny skład chemiczny [15]. Wtórne wykorzystanie szkła pozwala na oszczędność takich surowców jak soda i mączka wapienna, piasek jak i mniejszego zapotrzebowania na energię cieplną, co wpływa korzystnie na zmniejszenie produkcji dwutlenku węgla [15].
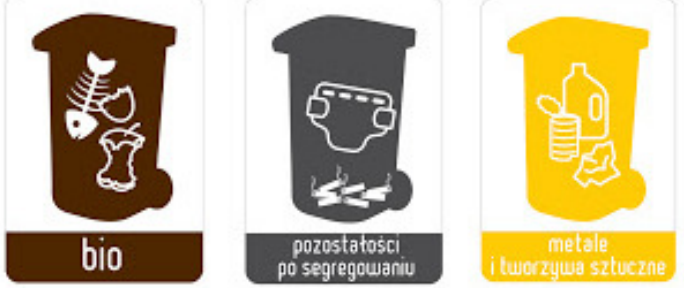

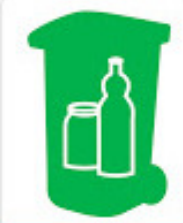

szkto

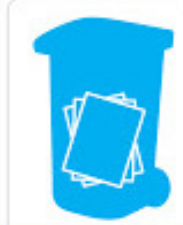

papier

Rysunek 1. Podziat segregacji odpadów ze względu na frakcje [20]

Jedna tona papieru poddana recyklingowi umożliwia oszczędność prawie 26,5 tys. litrów wody, zmniejsza ilość energii potrzebnej do wytworzenia papieru z surowców naturalnych i przyczynia się do zmniejszenia emisji gazów cieplarnianych [12]. Ponowne przetwarzanie papieru pozwala na wytworzenie na przykład filtrów do kawy, bandaży czy fartuchów ochronnych [12].

Odzyskiwanie tworzyw sztucznych $\mathrm{z}$ procesu recyklingu jest niezmiernie istotne ze względu na przewlekły czas biodegradacji [12] (reklamówka wykonana z plastiku może rozkładać się nawet 500 lat) segregując plastik chronimy środowisko przed toksynami wydzielanymi podczas rozkładu plastiku, ograniczamy straty energetyczne jak i zmniejszamy ogólną objętość odpadów [14] Z ponownie wykorzystanego plastiku możemy uzyskać długopisy, płyty termoizolacyjne, folie czy meble W Japonii znowu odpady komunalne dzieli się na sześć kategorii: odpady palne, niepalne, odpady zmieszane, wielogabarytowe oraz inne nadające się do recyklingu [16] ogrodowe [12].
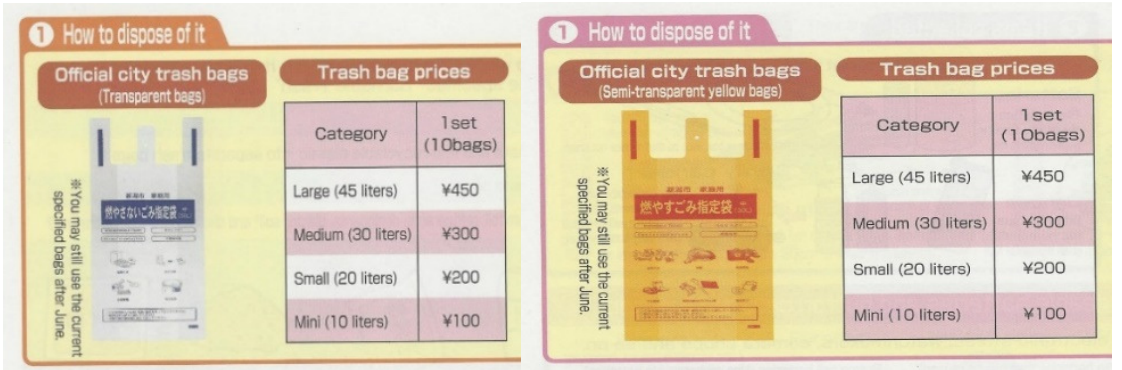

Rysunek 2. Odzyskiwanie tworzyw sztucznych z procesu recyklingu dla Japonii w latach 2015-2016 [16]

Odpady palne to przede wszystkim drewno, guma, odzież, odpady z tworzyw nienadające się do recyklingu i odpady skurzane takie odpadki wkłada nie do specjalnych żółtych worków [16]. Z kolei do białych wkłada się odpady niepalne takie jak szkło, metale czy ceramika [16]. Wielogabarytowe śmieci zbierane sią na żądanie za odpowiednią opłatą [16]. Japońskim rekordzistą w ilości 
segregowanych frakcji jest mała miejscowość o nazwie Kamikatsu - tam odpady segreguje się aż na 45 frakcji [16].

$\mathrm{Na}$ opakowaniach różnych produktów na przykład wody mineralnej, soków, mleka czy jogurtów znajdują się znaki informacyjne, z jakiego tworzywa dany produkt został stworzony [17]. Najczęściej można spotkać się z symbolem strzałek tworzących trójkąt $\mathrm{z}$ cyfrą $\mathrm{W}$ środku symbolizujący rodzaj materiału użyty do wytworzenia produktu [17].

\section{Projekt separatora powietrznego}

\subsection{Separacji odpadów za pomocą powietrza}

Do separacji odpadów za pomocą powietrza wykorzystuje się separator powietrzny inaczej zwany pneumatycznym, podobnie do wialni odseparowuje materiały lekkie od ciężkich[18]. Najczęściej używa się go do segregacji [19]:

- odpadów komunalnych zmieszanych,

- biomasy,

- $\quad$ odpadów przemysłowych takich jak guma czy inne tworzywa

- odpadów budowlanych

Separator pneumatyczny sortuje odpadki uderzając je od spodu strumieniem powietrza dzięki czemu te o niewielkiej masie na przykład folie, papier czy inne lekkie tworzywa sztuczne unoszą się do góry podczas gdy te cięższe lecą na dół [7]. W pierwszym etapie materiał oddziela się przy pomocy wialni a w kolejnym lekki materiał odprowadza się kanałami przez wentylator, który trafia do kontenera [7]. W tym samym czasie frakcje ciężkie spadają na znajdujący się poniżej taśmociąg. Separatory powietrzne mają dużą wydajność przy stosunkowo małym spożyciu energii, zastępuje czasochłonne sortowanie ręczne i zmniejsza koszty segregacji [7].

\subsection{Konstrukcja separatora powietrznego}

Założeniem separatora powietrznego jest wydzielenie frakcji styropianu od zmieszanych odpadów styropianowych, metalowych, plastikowych. Separator powietrzny wykorzystuje wytworzony ciąg powietrza za pomocą zastosowanego wentylatora, który oddziela lekkie frakcje od ciężkich. 


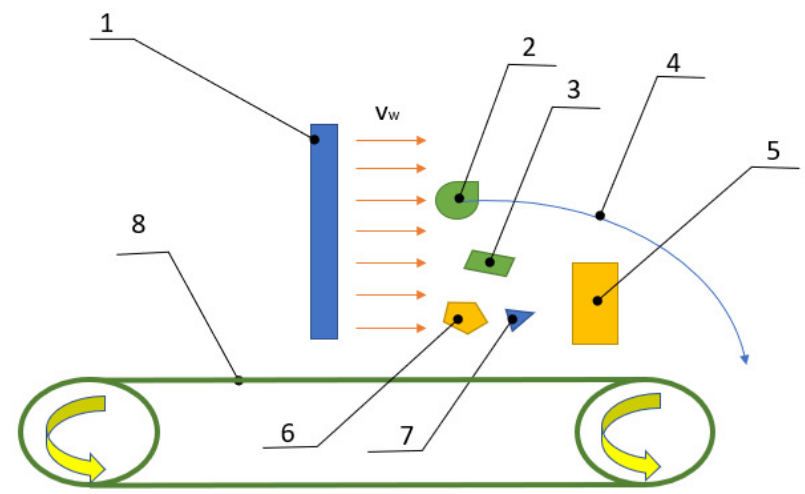

Rysunek 3. Schemat dziatania separatora powietrznego, 1-wentylator, 2-elementy styropianowe lub wióry drewniane, 3-elementy aluminiowe, 4- trajektoria lotu elementów styropianowych i wiórów drewnianych, 5 - przegroda stała, 6- elementy stalowe, 7- elementy plastikowe, 8- taśmociag główny

Prędkość wentylatora jest regulowana i została tak dobrana doświadczalnie, aby nie powodować zdmuchnięcia elementów stalowych, metali kolorowych, plastiku. Cięższe elementy opadają grawitacyjnie przez korpus urządzenia i spadają na taśmociąg główny, na którym nastąpi dalsza segregacja. Zasada działania separatora powietrznego przedstawiono na rys. 3.

Działanie oparte jest o spadające grawitacyjnie elementy styropianowe, (2), elementy aluminiowe (3), elementy stalowe (6), elementy plastikowe (7) poddane są działaniem pędu powietrza wytworzonego przez wentylator (1), w wyniku oddziaływania tego pędu następuje ich ruch w kierunku linii pędu wiatru. Elementy lekkie tj. styropian, wióry drewniane (2) zostaną przerzucone przez przegrodę (5), natomiast elementy ciężkie tj. stal (6), aluminium (3), plastik (7) nie przelecą przez przegrodę i opadną swobodnie w dół na taśmociąg główny, (8) na którym nastąpi dalsza segregacja frakcji. Na podstawie opisu zasady działania wialni zaprojektowano jej konstrukcję w programie SolidWorks rys. 4.

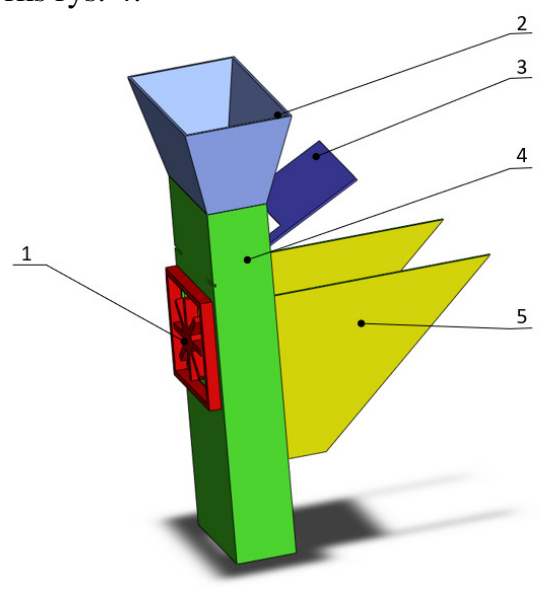

Rysunek 4. Separator powietrzny 1 -wentylator, 2-lej, 3- zasuwa, 4-korpus, 5- ostona 
Przedstawiony separator powietrzny wyposażony jest w korpus (4) stanowiący szkielet urządzenia wykonany został z profilu prostokątnego, od góry do korpusu (4) przymocowany jest lej (2) będący konstrukcją spawaną stanowi on zbiornik na wymieszane frakcje, które $\mathrm{w}$ dalszym etapie pracy urządzenia zostaną poddane segregacji, bezpośrednio pod lejem (2) znajduje się zasuwa (3) służąca do sterowania prędkością podawania frakcji, z przodu korpusu (4) zamocowany jest wentylator za pomocą 4 śrub M4, wentylator(1) o regulowanej prędkości obrotowej służy do oddzielenia frakcji lekkich tj. styropianu, wiórów drewnianych, wytworzony przez niego ciąg powoduje wylot lekkich frakcji do worka mocowanego na osłonach (5).

\section{Wyznaczenie wymiarów geometrycznych korpusu wialni}

$\mathrm{Na}$ przelatujące frakcje $\mathrm{w}$ wialni oddziałuje pęd powietrza wytworzony poprzez wentylator. Założono, że w projekcie zastosuje się wentylator komputerowy o parametrach przedstawionych na rys. 3.4.

- Producent: SilentiumPC

- Model: SPC015

- Kod producenta: SPC015

- Rozmiar wentylatora: 92 x 92 $\mathrm{mm}$

- EAN: 5900308750940

- Wtyczka zasilająca: 3-pin PWM

- Prędkość: 1300 obr/min

- Przepływ powietrza: 57,41CFM

- Max poziom hałasu: 13,9 dBA

- Waga: 0,091kg

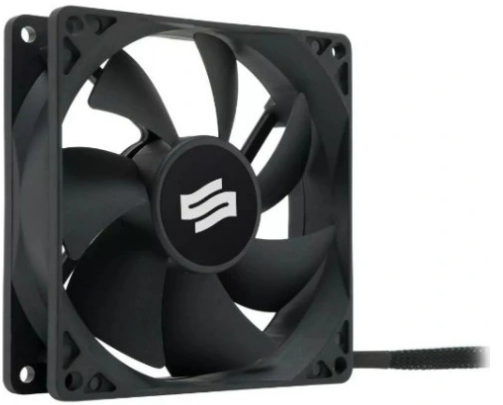

Rysunek 5. Wentylator [22]

- Napięcie zasilania: 12VDC

Dla tak przyjętego wentylatora wyznaczono odległość, na jaką przemieści się cząstka styropianu. Założono, że maksymalny ciężar cząstki do segregacji wyniesie $\mathrm{m}=$ $0.008 \mathrm{~kg}$. Schemat przemieszczania się cząstki wpadającej w działanie pędu powietrza przedstawiono na rys. 3.5 .

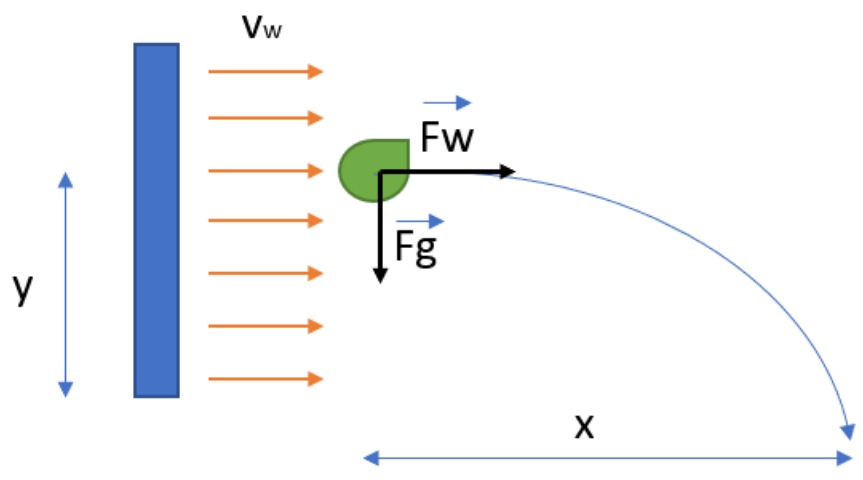

Rysunek 6. Schemat przemieszczania się cząstki wpadającej w działanie pędu powietrza y-odległość na jaka opadnie czastka w osi y, $x$-odległość na jaka opadnie cząstka w osi x, Fw-siła wiatru działająca na cząstkę, Fg-siła ciężkości działającej na czastke 
Na spadającą cząstkę w wialni działa siła ciężkości Fg oraz siła wiatru Fw powodują one, że cząstka zaczyna się przemieszczać po krzywej przedstawionej na rys. 6 .

Siłę ciężkości wyznaczono z zależności:

$$
F_{g}=m * g,
$$

gdzie:

$\mathrm{m}=0,008 \mathrm{~kg}-$ masa cząstki,

$\mathrm{g}=10 \mathrm{~m} / \mathrm{s}^{2}-$ przyspieszenie ziemskie.

Po podstawieniu mamy :

$$
F_{g}=m * g=0,008 * 10=0,08 N .
$$

Siła pochodząca od wiatraka działa na cząstkę od momentu kiedy wchodzi w przestrzeń działania wentylatora do momentu wyjścia $\mathrm{z}$ zasięgu działania wentylatora.tj. wysokość wentylatora wynoszącą $\mathrm{y}=92 \mathrm{~mm}$. W tym czasie cząstka w pionie pokona ten dystans który można wyznaczyć z zależności na drogę $\mathrm{w}$ ruchu jednostajnie przyspieszonym:

$$
y=\frac{g * t^{2}}{2}
$$

gdzie:

$\mathrm{g}=10 \mathrm{~m} / \mathrm{s}^{2}-$ przyspieszenie ziemskie,

$\mathrm{y}=0,092 \mathrm{~m}-$ wysokość wentylatora,

$\mathrm{t}$ - czas przelotu cząstki w polu zasięgu wentylatora.

Po przekształceniu otrzymujemy:

$$
t=\sqrt{\frac{2 * y}{g}}=\sqrt{\frac{2 * 0,092}{10}}=0,14 s,
$$

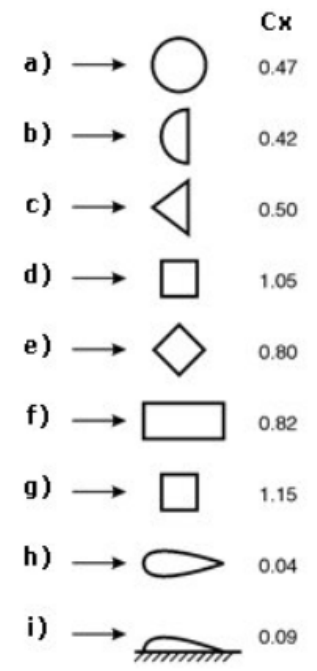

Rysunek 7. Wartości wspótczynnika oporów aerodynamicznych $w$ zależności od ksztattu elementu [20]

Siłę powietrza działającą na cząstkę wyznaczono z zależności: 


$$
F_{w}=0,5 * p * c_{x} * A * v^{2},
$$

gdzie:

$$
\begin{aligned}
& \mathrm{p}=1,21 \mathrm{~kg} / \mathrm{m}^{3}-\text { gęstość powietrza, } \\
& \mathrm{c}_{\mathrm{x}}-\text { współczynnik oporów aerodynamicznych }
\end{aligned}
$$

Frakcja lekka, która ma pozostać odseparowana charakteryzuje się nieregularnym kształtem. Dlatego założono, że przyjmie się do obliczeń średnią wartość współczynnika oporów aerodynamicznych c $\mathrm{c}_{\mathrm{x}}$ rys. 7 .

$\mathrm{Z}$ przedstawionych na rys. 7. wartości współczynnika oporów aerodynamicznych wartość średnia wynosi:

$$
c_{x}=\frac{0,47+0,42+0,5+1,05+0,8+0,82+1.15+0,04+0,09}{9}=0,6,
$$

I taką przyjęto w dalszych obliczeniach.

Założono, że przekrój poprzeczny powierzchni cząstki na jaką działa powietrze wyniesie $4 \mathrm{~mm}^{2}$

$\mathrm{Na}$ podstawie danych podanych przez producenta wentylator posiada wydajność $\mathrm{Q}_{\mathrm{w}}=57,41 \mathrm{CFM}$ co odpowiada $0,027 \mathrm{~m}^{3} / \mathrm{s}$

Dodatkowo średnica łopatek wirnika wentylatora wynosi $\mathrm{d}=85 \mathrm{~mm}$. Na podstawie wydajności wentylatora oraz średnicy jego łopatek wyznaczono prędkość z jaką poruszą się powietrze wzbudzone przez wentylator rys. 3.7.

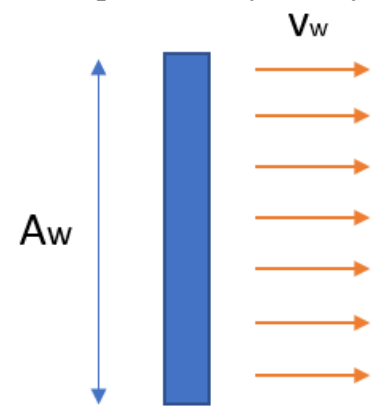

Rysunek 8. Schemat pracy wentylatora Aw- powierzchnia wentylatora, $v_{w}$-prędkość wytworzonej strugi powietrza

$$
Q_{w}=A_{w} * v_{w},
$$

gdzie:

$$
A_{w}=\frac{\pi * d^{2}}{4}=\frac{\pi * 0,085^{2}}{4}=0,018 m^{2},
$$

Stąd po przekształceniu mamy:

$$
v_{w}=\frac{Q_{w}}{A_{w}}=\frac{0,027}{0,018}=1,5 \mathrm{~m} / \mathrm{s},
$$

Mając wyznaczoną prędkość powietrza możemy wrócić do wyznaczenia siły działającej na cząstkę w wialni: 


$$
\begin{aligned}
& F_{w}=0,5 * p * c_{x} * A * v^{2} \\
& F_{w}=0,5 * 1,21 * 0,6 * 4 * 10^{-4} * 1,5^{2}=0,4 N,
\end{aligned}
$$

$\mathrm{Na}$ cząstkę w kierunku poziomym działa stała siła pochodząca od wentylatora $\mathrm{F}_{\mathrm{w}}$ nadając jej przyspieszenie:

gdzie

$$
F_{w}=a * m,
$$

a - przyspieszenie cząstki,

$\mathrm{m}=0,008 \mathrm{~kg}-$ masa analizowanej cząstki.

Stąd po przekształceniu otrzymujemy:

$$
a=\frac{F_{w}}{m}=\frac{0,4}{0,008}=50 \mathrm{~m} / \mathrm{s}^{2},
$$

Siła pochodząca od pędu powietrza działa na cząstkę powodując jej przyspieszanie do momentu osiągnięcia przez cząstkę prędkości strugi powietrza tj. $\mathrm{v}_{\mathrm{w}}=1,5 \mathrm{~m} / \mathrm{s}$ po osiągnięciu tej prędkości cząstka porusza się ruchem jednostajnym z tą prędkością. Czas, w jakim cząstka osiągnie taką prędkość wyznaczamy ze wzoru na przyspieszenie $\mathrm{w}$ ruchu jednostajnie przyspieszonym:

$$
a=\frac{v_{w}}{t_{1}}
$$

gdzie:

$\mathrm{a}=50 \mathrm{~m} / \mathrm{s}^{2}-$ przyspieszenie cząstki,

$\mathrm{V}_{\mathrm{w}}=1,5 \mathrm{~m} / \mathrm{s}$ - prędkość powietrza pochodząca od wentylatora,

$\mathrm{t}_{1}$ - czas $\mathrm{w}$ jakim cząstka uzyska prędkość $1,5 \mathrm{~m} / \mathrm{s}$

Po przekształceniu powyższego wzoru otrzymujemy:

$$
\mathrm{t}_{1}=\frac{v_{w}}{a}=\frac{1,5}{50}=0,03 \mathrm{~s},
$$

W tym czasie cząstka pokona odległość $\mathrm{x}_{1}$ :

$$
x_{1}=\frac{a * t_{1}^{2}}{2}=\frac{50 * 0,03^{2}}{2}=0,022 \mathrm{~m},
$$

Przez pozostały czas, w którym cząstka znajduje się w zasięgu działania pędu powietrza pochodzącego od wentylatora $\mathrm{tj}$.:

$$
t_{2}=t-t_{1} \text {, }
$$

gdzie:

$\mathrm{t}=0,41 \mathrm{~s}-$ czas $\mathrm{w}$ jakim cząstka znajduje się $\mathrm{w}$ zasięgu działania wentylatora wyznaczony ze swobodnego spadku cząstki,

$\mathrm{t}_{1}=0,03 \mathrm{~s}-$ czas $\mathrm{w}$ jakim cząstka przyspiesza do prędkości strugi powietrza $\mathrm{tj}$. $1,5 \mathrm{~m} / \mathrm{s}$

$\mathrm{t}_{2}$ - czas w którym cząstka porusza się ze stałą prędkością 1,5m/s i znajduje się jeszcze w zasięgu działania wentylatora

$t_{2}=0,41-0,03=0,38 s$,

$\mathrm{W}$ czasie $\mathrm{t}_{2}$ cząstka porusza się ruchem jednostajnym na odległość $\mathrm{x}_{2}$ :

$$
x_{2}=v_{w} * t_{2}=1,5 * 0,38=0,19 m,
$$


Podsumowując cząstka $\mathrm{w}$ kierunku działania pędu powietrza przemieści się na odległość x:

$$
x=x_{1}+x_{2}=0,022+0,19=0,212 m,
$$

gdzie: $\quad \mathrm{x}_{1}=0,022 \mathrm{~m}-$ droga jaką uzyska cząstka przyspieszając do prędkości strugi powietrza $\mathrm{tj} .1,5 \mathrm{~m} / \mathrm{s}$

$\mathrm{x}_{2}=0,19 \mathrm{~m}-$ droga jaką uzyska cząstka znajdując się jeszcze w zasięgu działania wentylatora, poruszając się ze stałą prędkością 1,5 m/s $\mathrm{x}$ - całkowita droga jaką przebędzie cząstka znajdująca się $\mathrm{w}$ polu zasięgu działania wentylatora.

Mając na uwadze powyższe obliczenie dokonano wykonania rysunków wykonawczych w programie SolidWorks. Rysunki wykonawcze poszczególnych elementów wialni przedstawione są na rysunkach (rys. 9-12).
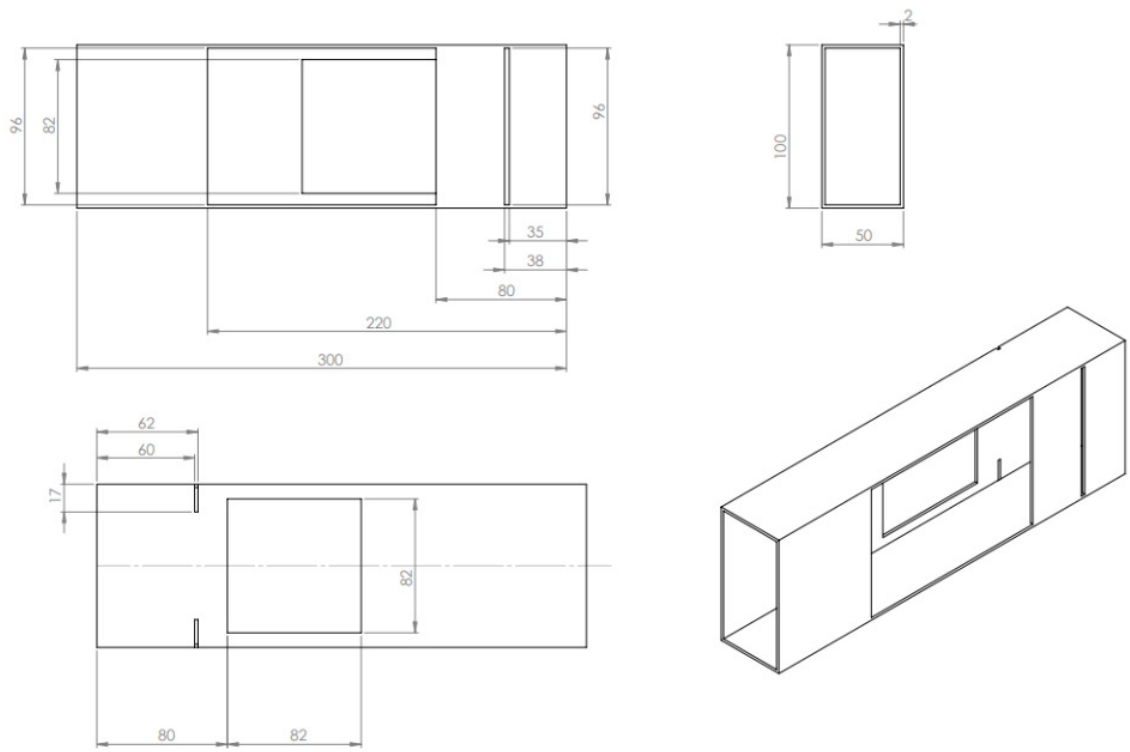

Rysunek 9. Korpus
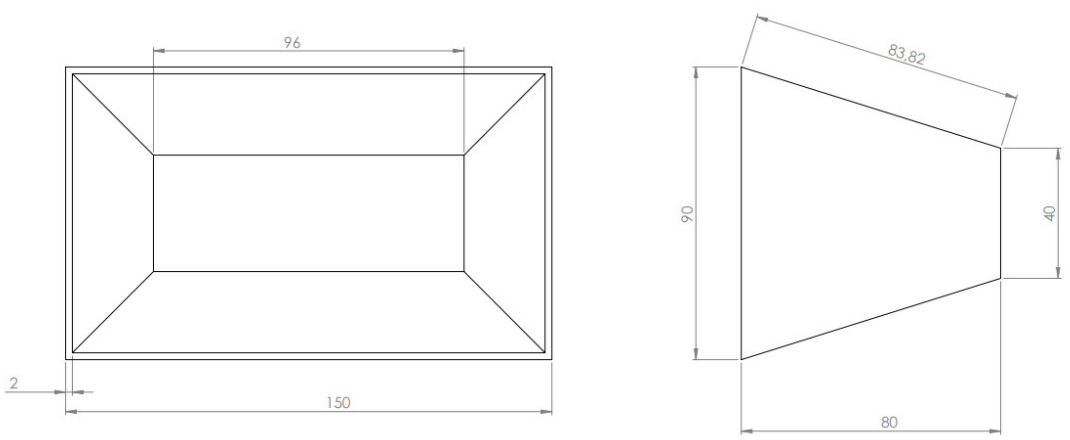

Rysunek 10. Lej 

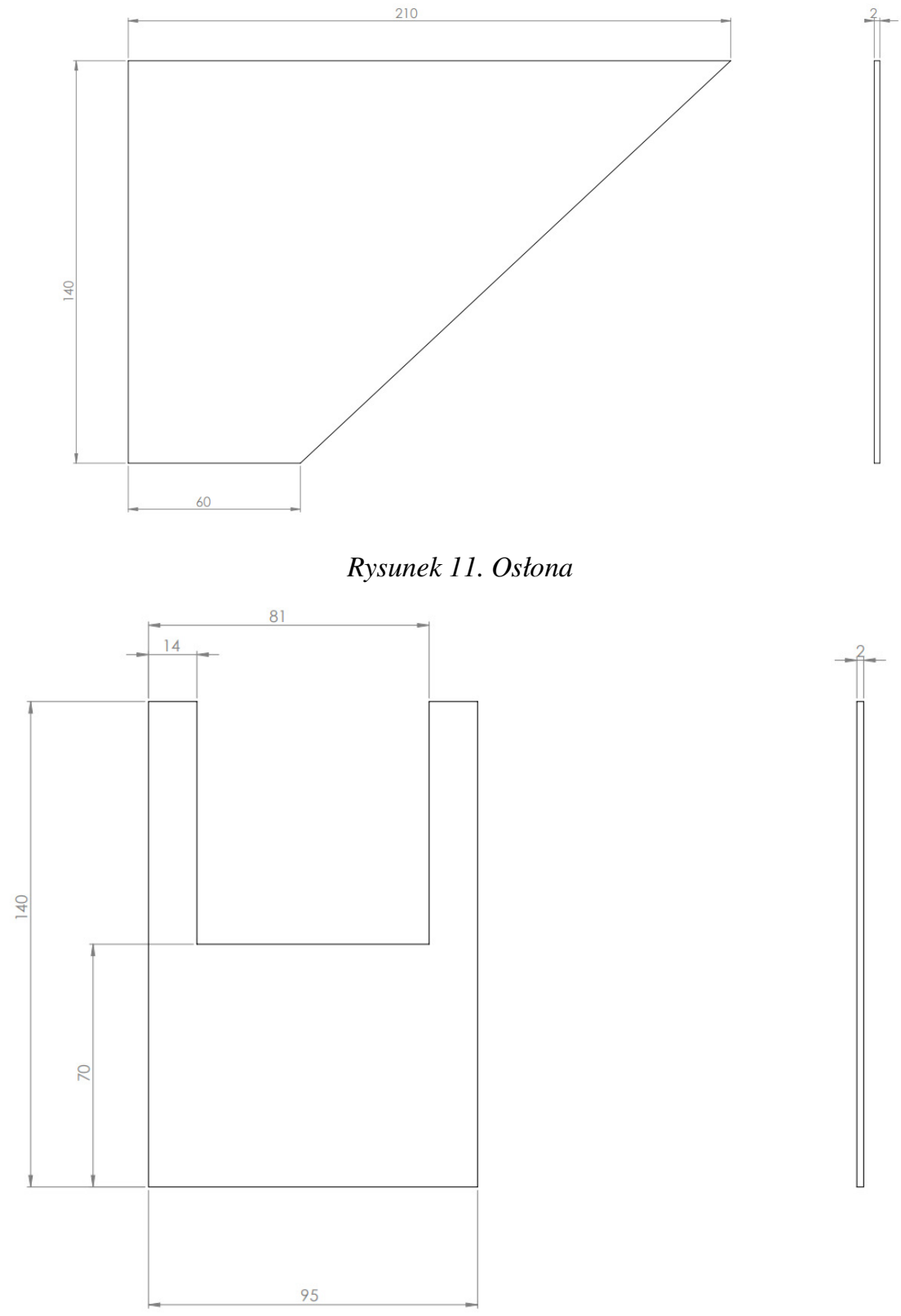

Rysunek 12. Zasuwa

Na podstawie powyższych rysunków wykonawczych został wykonany separatora powietrzny metodą spawania elektrodą otuloną. Porównanie wialni zaprojektowanej, a wykonanej przedstawiono na rys. 3.12. 

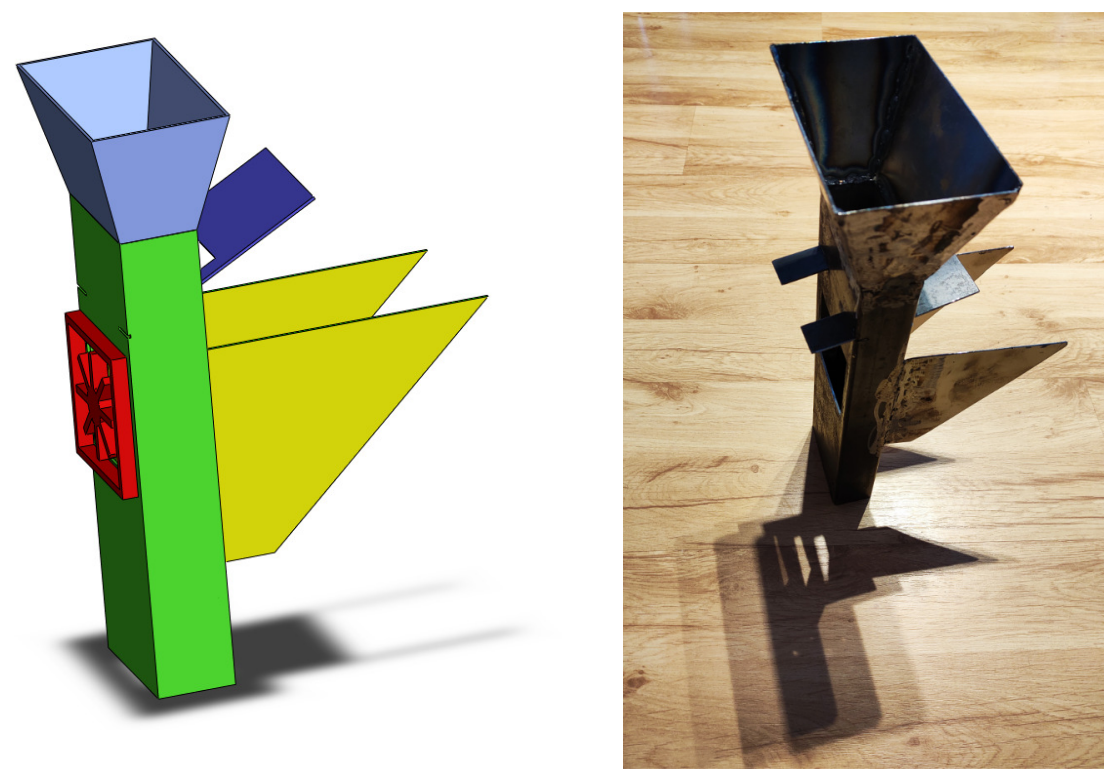

Rysunek 13. Porównanie projektu separatora powietrznego z gotowym przedmiotem

\section{Podsumowanie}

Separator powietrzny po zaprojektowaniu i wykonaniu został przetestowany w rzeczywistych warunkach. Testy polegały na sprawdzeniu skuteczności odseparowania cząstek styropianu od innych zmieszanych frakcji. W wyniku przeprowadzonych testów można stwierdzić, że skuteczność odseparowania wynosi 95\%. Co potwierdza skuteczność wykonanych obliczeń i wykonania części mechanicznej.

\section{LITERATURA}

1. Dyrektywa 2008/98/WE Parlamentu Europejskiego i Rady w sprawie odpadów oraz uchylająca inne dyrektywy z dnia 19 listopada $2008 \mathrm{r}$.

2. Serwis internetowy: https://www.mos.gov.pl/ -20.02 .2021$

3. Dyrektywa 99/31/WE w sprawie składowisk odpadów z 26 kwietnia 1999 r.

4. Dz. U. z 2008 r. nr 25 poz. 150 , ustawa Prawo Ochrony Środowiska z dnia 27 kwietnia $2001 \mathrm{r}$.

5. Dz. U. z 2001r. nr 100, poz. 1085 wprowadzenie ustawy- Prawo ochrony środowiska, ustawy o odpadach oraz zmiana niektórych ustaw.

6. Dz. U. z 2013r. poz. 2, ustawa o odpadach z dnia 14 grudnia 2012 r. tekst jednolity.

7. GÓRSKI M.: Składowanie odpadów Cz. I, Przegląd Komunalny, 2013.

8. Rozporządzenie Ministra Gospodarki i Pracy z dnia 7 września 2005r. w sprawie określenia kryteriów i procedur dopuszczenia odpadów do składowania na 
składowiskach odpadów niebezpiecznych, obojętnych, innych niż niebezpieczne i obojętne ( Dz. U. z 2005r. nr 186, poz.1553)

9. Rozporządzenie Rady Ministrów z dnia 10 maja 2005 r. zmieniające rozporządzenie w sprawie określenia rodzajów przedsięwzięć mogących znacząco oddziaływać na środowisko oraz szczegółowych uwarunkowań związanych z kwalifikowaniem przedsięwzięcia do sporządzenia raportu o oddziaływaniu na środowisko ( Dz. U. z 2005r. nr 92, poz. 769).

10. ROSIK-DULEWSKA CZ., Podstawy gospodarki odpadami. Wyd. Wydawnictwo Naukowe PWN, Warszawa 2006.

11. KOZŁOWSKA B.: Transformacja składowisk odpadów komunalnych w PolsceDostosowanie pozwoleń zintegrowanych do bieżących przepisów prawnych\|, XX Jubileuszowa Ogólnopolska Konferencja Szkoleniowa „Budowa i eksploatacja bezpiecznych składowisk odpadów, Szklarska Poręba - Praga 2010.

12. KRYZA H.: Oddziaływanie wysypiska odpadów komunalnych w Szymiszowie na wody podziemne głównego zbiornika wód podziemnych nr 333 OpoleZawadzkie. Technika Poszukiwań Geologicznych, 2003.

13. OLESZKIEWICZ J.: Eksploatacja składowiska odpadów- Poradnik decydenta. Wyd. Lem Projekt s.c., Kraków1999.

14. Serwis internetowy: https://portalkomunalny.pl/segregacja-smieci-2021-jaksegregowac-odpady-390215/ -07.02.2021

15. Serwis internetowy: https://artglas-recykling.pl/recykling-stluczki-szklanej-wpolsce-i-na-swieciel -07.02.2021

16. Serwis internetowy: http://ekordo.pl/segregacja-odpadow-po-japonsku/ 08.02.2021

17. Serwis internetowy: https://famag.pl/edukacja/oznaczenia-bez-tajemnic/ 08.02.2021

18. Dyrektywa 2008/98/WE Parlamentu Europejskiego i Rady w sprawie odpadów oraz uchylająca inne dyrektywy z dnia 19 listopada $2008 \mathrm{r}$.

19. Dz. U. z 2013r. poz. 2, ustawa o odpadach z dnia 14 grudnia 2012 r. tekst jednolity.

20. Serwis internetowy: http://czystemiasto.bielsko-biala.pl/rodzaje-odpadow 09.02.2021

21. Serwis internetowy: http://www.technikajazdy.info/techniczne/wspolczynnikoporu-powietrza/ - 16.09.2021

22. Serwis internetowy: https://www.morele.net/wentylator-silentiumpc-zephyr-92spc015-321484/-16.09.2021 